\title{
Osteosclerotic Plasma Cell Myeloma
}

National Cancer Institute

\section{Source}

National Cancer Institute. Osteosclerotic Plasma Cell Myeloma. NCI Thesaurus. Code C7765.

A plasma cell neoplasm associated with osteosclerotic and fibrotic chang es in the bone trabeculae. Often, the lymph nodes show changes resembling the plasma cell variant of Castleman disease. It is often part of POEMS syndrome which is characterized by polyneuropathy, organomegaly, endocrinopathy, monoclonal gammopathy, and skin changes. 